\title{
AN OVERVIEW OF INDUSTRIAL SOFTWARE DOCUMENTATION PRACTICES
}

\author{
Marcello Visconti ${ }^{1}$ \\ Departamento de Informática \\ Universidad Técnica Federico Santa María \\ Valparaíso, CHILE \\ visconti@inf.utfsm.cl \\ Curtis R. Cook \\ Computer Science Department \\ Oregon State University \\ Corvallis, Oregon, USA \\ cook@cs.orst.edu
}

April 2000

\begin{abstract}
A system documentation process maturity model and assessment procedure were developed and used to assess 91 projects at 41 different companies over a seven year period. During this time the original version evolved into a total of four versions based on feedback from industry and the experience gained from the assessments. This paper reports the overall results obtained from the assessments which strongly suggest that the practice of documentation is not getting a passing grade in the software industry. The results show a clear maturity gap between documentation practices concerned with defining policy and practices concerned with adherence to those policies. The results further illustrate the need to recognize the importance of improving the documentation process, and to transform the good intentions into explicit policies and actions.
\end{abstract}

Keywords: system documentation processes, maturity model, key practices, degree of satisfaction, assessment results

\section{INTRODUCTION}

The purpose of this paper is to report the results after using a system documentation process maturity model and assessment procedure to assess 41 companies involving 91 projects and over 370 software professionals in a period of seven years. The essence of the model remained unchanged throughout its first three versions, but industry feedback as well as the experience gained during the assessments led to modifications of key practices and question

\footnotetext{
${ }^{1}$ This research has been funded in part by the National Commission on Scientific and Technological Research of the Government of Chile, CONICYT, through research project FONDECYT \#1990845
} 
scoring scheme which are explained elsewhere [11]. Then, a fourth version changed the model structure to one without the maturity levels as an indicator of process maturity that focused on the key practices. This evolution led to the formulation of a process maturity meta-model, further explained in [13].

In this paper we describe the general state of the practice of the system documentation process based on the assessments results. To facilitate comparisons between the results from the different assessments using the distinct versions, only the key practice profiles are used. The maturity levels computed for the first three versions are shown for illustration purposes only. Maturity levels were not part of the fourth version.

The idea behind the Documentation Process Maturity Model is very simple: most defects discovered during software testing are documentation defects (requirements and design defects - defects in documentation that were introduced before any code was written). Empirical studies have shown that poor quality, out of date, or missing documentation is a major cause of defects in software development and maintenance [1,2,8,9]. Thus, documentation is a key component in software quality and improving the documentation process will have considerable impact on improving the quality of software. Our solution scheme has been to design a maturity model that provides the basis for the assessment of current documentation process and guides the identification of key practices and challenges to improve the process [10]. The focus is on the documentation used in software development and maintenance and does not consider end-user documentation. Our approach has been influenced by the Capability Maturity Model $\left(\mathrm{CMM}^{\mathrm{sm}}\right)$ developed by Carnegie Mellon University's Software Engineering Institute (SEI) [4,6,7].

This paper is organized as follows: next section presents the Documentation Process Maturity Model and discusses its foundations and related research that led to its formulation. The following section highlights the major changes performed from the first three versions to the fourth in terms of model structure, and gives a summary of the model evolution. Then, the results obtained from the assessments conducted with each version are shown. The final section discusses the state of the practice of software documentation based on the assessment results, and gives our conclusions and projections for further research work.

\section{DOCUMENTATION PROCESS MATURITY MODEL - FRAMEWORK AND EVOLUTION}

The Documentation Process Maturity Model (DPMM) is a description of process maturity, capability and practices that characterize an organization that generates high quality documentation. (Recall that documentation refers to the system documentation generated as part of the software development process. It does not include end-user documentation.) A four level software system documentation process maturity model and assessment procedure have been developed. The model represents an ideal process and the assessment determines where the organization stands relative to the model. The model and assessment procedure were influenced by CMM in that key practices, indicators, and challenges are

$\mathrm{CMM}^{\mathrm{sm}}$ is a service mark of Carnegie Mellon University 
defined for each of the four levels of the model; for the assessment procedure a questionnaire, that takes only 30 minutes to complete, is administered to each member of the project team. The tabulated questionnaire responses are used to generate an assessment report that gives the maturity level and a documentation process profile that indicates what practices the organization is doing well, what practices need improvement, and challenges to move to the next higher maturity level. More information about the context framework that was the supporting basis to develop the maturity model and related assessment procedure is given in [10]. The model's overall structure is presented in Table 1.

Table 1. Documentation Process Maturity Model - Summary

\begin{tabular}{|c|c|c|c|c|}
\hline & $\begin{array}{l}\text { Level } 1 \\
\text { Ad-hoc }\end{array}$ & $\begin{array}{c}\text { Level } 2 \\
\text { Inconsistent }\end{array}$ & $\begin{array}{l}\text { Level } 3 \\
\text { Defined }\end{array}$ & $\begin{array}{c}\text { Level } 4 \\
\text { Controlled }\end{array}$ \\
\hline Keywords & $\begin{array}{l}\text { Chaos, } \\
\text { Variability }\end{array}$ & $\begin{array}{l}\text { Standards } \\
\text { Check-off list } \\
\text { Inconsistency }\end{array}$ & $\begin{array}{l}\text { Product assessment } \\
\text { Process definition }\end{array}$ & $\begin{array}{l}\text { Process assessment } \\
\text { Measurement } \\
\text { Control } \\
\text { Feedback } \\
\text { Improvement }\end{array}$ \\
\hline $\begin{array}{c}\text { Succinct } \\
\text { Description }\end{array}$ & $\begin{array}{l}\text { Documentation not a } \\
\text { high priority }\end{array}$ & $\begin{array}{l}\text { Documentation } \\
\text { recognized as } \\
\text { important and must } \\
\text { be done. }\end{array}$ & $\begin{array}{l}\text { Documentation } \\
\text { recognized as } \\
\text { important and must } \\
\text { be done well. }\end{array}$ & $\begin{array}{l}\text { Documentation } \\
\text { recognized as } \\
\text { important and must } \\
\text { be done well } \\
\text { consistently }\end{array}$ \\
\hline $\begin{array}{c}\text { Key } \\
\text { Practices }\end{array}$ & $\begin{array}{l}\text { Ad-hoc process } \\
\text { Not important }\end{array}$ & $\begin{array}{l}\text { Inconsistent } \\
\text { application of } \\
\text { standards }\end{array}$ & $\begin{array}{l}\text { Documentation } \\
\text { quality assessment } \\
\text { Documentation } \\
\text { usefulness assurance } \\
\text { Process definition }\end{array}$ & $\begin{array}{l}\text { Process quality } \\
\text { assessment and } \\
\text { measures }\end{array}$ \\
\hline $\begin{array}{c}\text { Key } \\
\text { Indicators }\end{array}$ & $\begin{array}{l}\text { Documentation } \\
\text { missing or out of } \\
\text { date }\end{array}$ & $\begin{array}{l}\text { Standards } \\
\text { established and use } \\
\text { of check-off list }\end{array}$ & SQA-like practices & $\begin{array}{l}\text { Data analysis and } \\
\text { improvement } \\
\text { mechanisms }\end{array}$ \\
\hline $\begin{array}{c}\text { Key } \\
\text { Challenges }\end{array}$ & $\begin{array}{l}\text { Establish } \\
\text { documentation } \\
\text { standards }\end{array}$ & $\begin{array}{l}\text { Exercise quality } \\
\text { control over content } \\
\text { Assess } \\
\text { documentation } \\
\text { usefulness } \\
\text { Specify process }\end{array}$ & $\begin{array}{l}\text { Establish process } \\
\text { measurement } \\
\text { Incorporate control } \\
\text { over process }\end{array}$ & $\begin{array}{l}\text { Automate data } \\
\text { collection and } \\
\text { analysis } \\
\text { Continually striving } \\
\text { for optimization }\end{array}$ \\
\hline
\end{tabular}

A key to understanding DPMM is the succinct description of each of the four levels in the model, as shown in Table 1. The four succinct descriptions are: Level 1 - all the required documentation may not be done; Level 2 - all the required documentation is done; Level 3 all the required documentation is done well and attention is paid to the usefulness of the documentation; and Level 4 - an optimizing loop where measurement of the process and usability provide feedback to continually improve the process.

It is important to notice that for the fourth and last version of the model we have dropped the maturity level idea and have only concentrated on key practices. The reason is that in our experience maturity levels seemed to draw attention away from what is really the key issue in software process improvement: the key practices. We have extended this idea and have proposed a meta-model to identify key practices that also considers a product dimension (in terms of quality assurance and usability) when assessing a particular process 
during the diagnosis phase. This shows to be especially important when the process produces tangible deliverables, as is the case of the documentation process. Further details are available in [13].

DPMM has evolved over four versions. In the first three versions, each of the four levels has a number of key practices associated with it. Version 4 of DPMM only has a set of associated key practices and no maturity levels. In versions 3 and 4 , a number of subpractices were associated with each key practice. Table 2 shows a summary to illustrate the evolution the model has undergone over the four versions. These changes are the result of documentation process assessments performed in the industry, assessing over 90 projects at more than 40 organizations. Full details of the evolution over the first three versions are available in [11].

Table 2. Summary - Evolution of DPMM

\begin{tabular}{|c||c||c|c||c||c|c||}
\hline Version & $\begin{array}{c}\text { Maturity } \\
\text { Levels }\end{array}$ & $\begin{array}{c}\text { Key } \\
\text { Practices }\end{array}$ & $\begin{array}{c}\text { Sub } \\
\text { Practices }\end{array}$ & Questions & $\begin{array}{c}\text { Assessed } \\
\text { Companies }\end{array}$ & $\begin{array}{c}\text { Assessed } \\
\text { Projects }\end{array}$ \\
\hline \hline 1 & 4 & 18 & n/a & 56 & 7 & 26 \\
\hline \hline 2 & 4 & 19 & n/a & 68 & 13 & 34 \\
\hline \hline 4 & 4 & 9 & 26 & 67 & 9 & 19 \\
\hline \hline 4 & n/a & 11 & 32 & 75 & 12 & 12 \\
\hline
\end{tabular}

Table 3 shows a list of all key practices identified for each version, indicating which ones have remained unmodified, which have been dropped and which have been added. It is important to note that in Table 3 a key practice that was rewritten or modified appears as a dropped key practice and later as an added key practice. For example the key practice Use of a check-off list of required documents in version 1 was modified to Mechanism to check that required documentation is done in versions 2 and 3. In other cases, some dropped key practices became subpractices of later versions, so they were not actually dropped either. Subpractices are not shown in Table 3. Only one key practice remained unmodified for all four versions: Process improvement feedback loop.

To carry out the assessments we have used an assessment questionnaire, whose purpose is to determine where an organization's documentation process stands relative to the model. The assessment questions are derived directly from the model and its key practices. There are one or more questions for each key practice. The process maturity level (for the first three versions) and the degree of key practice satisfaction are determined from the questionnaire responses. For version 1 the key practices were rated as Not Satisfied, Partially Satisfied, or Fully Satisfied. This rating system seemed ambiguous and too coarse as there was a wide latitude in the degree of key practice satisfaction especially when a practice was classified as Partially Satisfied. For example, does Partially Satisfied mean the key practice is satisfied seldom or often or half of the time? Not Satisfied and Fully Satisfied were also ambiguous. Does Not Satisfied mean never or most of the time it is not satisfied? Does Fully Satisfied mean always or most of the time? To eliminate these ambiguities, from version 2 on there was a change from three to five degrees of satisfaction as follows: Very High, High, Medium, Low and Very Low. 
Each person on a project team completed the assessment questionnaire. The degree of satisfaction of a key practice was generally determined by the average of the responses to the questions associated with that key practice.

Table 3. Summary - Evolution of Key Practices of DPMM

\begin{tabular}{|c|c|c|c|c|}
\hline Key Practices of DPMM & Version 1 & Version 2 & Version 3 & Version 4 \\
\hline Consistent creation of basic software development documents & $\mathrm{X}$ & $\bar{X}$ & & \\
\hline Creation of basic software documents & & & & $\overline{\mathrm{X}}$ \\
\hline Documentation generally recognized as important & $\mathrm{X}$ & $\mathrm{X}$ & & \\
\hline Written statement or policy about importance of documentation & $\overline{\mathrm{X}}$ & $\overline{\mathrm{X}}$ & & \\
\hline Management recognition of importance of documentation & & & & $\overline{\mathrm{X}}$ \\
\hline Adequate time and resources for documentation & $\bar{X}$ & & & \\
\hline Adequate time for documentation & & $\overline{\mathrm{X}}$ & & \\
\hline Existence of documentation policy or standards & & $\overline{\mathrm{X}}$ & X & $\overline{\mathrm{X}}$ \\
\hline Monitor implementation of policy or standards & & & & $\bar{X}$ \\
\hline Adherence to documentation standards & $\overline{\mathrm{X}}$ & & & \\
\hline Adherence to documentation policy or standards & & $\overline{\mathrm{X}}$ & $\overline{\mathrm{X}}$ & \\
\hline Use of check-off list of required documentation & $\overline{\mathrm{X}}$ & & & \\
\hline Mechanism to check that required documentation is done & & $\bar{X}$ & $\overline{\mathrm{X}}$ & \\
\hline Use of simple documentation tools & $\mathrm{X}$ & $\mathrm{X}$ & & \\
\hline Accuracy and reliability of documentation & $\mathrm{X}$ & $\mathrm{X}$ & & \\
\hline Mechanisms to update documentation & $\overline{\mathrm{X}}$ & $\bar{X}$ & & \\
\hline Existence of a defined process for creation of documents & & & $\overline{\mathrm{X}}$ & $\overline{\mathrm{X}}$ \\
\hline Mechanisms to monitor quality of documentation & $\overline{\mathrm{X}}$ & $\overline{\mathrm{X}}$ & 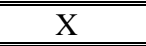 & \\
\hline Methods to assure quality of documentation & & & & $\overline{\mathrm{X}}$ \\
\hline Methods to assess usefulness of documentation & $\bar{X}$ & $\bar{X}$ & & \\
\hline Assessment of usefulness of documentation & & & $\overline{\mathrm{X}}$ & \\
\hline Assessment of usability of documentation & & & & $\overline{\mathrm{X}}$ \\
\hline Use of common sets of documentation tools & $\overline{\mathrm{X}}$ & $\bar{X}$ & & \\
\hline Use of advanced documentation tools & $\overline{\mathrm{X}}$ & $\overline{\mathrm{X}}$ & & \\
\hline Documentation-related technology and training & $\overline{\mathrm{X}}$ & $\overline{\mathrm{X}}$ & & \\
\hline Documentation is traceable to previous documents & & $\mathrm{X}$ & & \\
\hline Definition of software documentation quality and usability measures & & & & $\mathrm{X}$ \\
\hline Measures of documentation process quality & $\overline{\mathrm{X}}$ & $\bar{X}$ & & \\
\hline Measures of documentation process quality and usefulness & & & 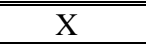 & \\
\hline Collection and analysis of documentation quality measures & & & & 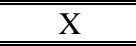 \\
\hline Analysis of documentation usage and usefulness & $\mathrm{X}$ & $\bar{X}$ & & \\
\hline Analysis of documentation process quality and usefulness & & & $\overline{\mathrm{X}}$ & \\
\hline Collection and analysis of documentation usability measures & & & & $\mathrm{X}$ \\
\hline Process improvement feedback loop & $\overline{\mathrm{X}}$ & $\overline{\mathrm{X}}$ & $\overline{\mathrm{X}}$ & $\bar{X}$ \\
\hline Integrate CASE and documentation tools & $\mathrm{X}$ & & & \\
\hline
\end{tabular}

Finally, an assessment report is generated from the questionnaire responses. The report contains an executive summary with the maturity level (only for the first three versions), a documentation process maturity profile and an improvement action plan. Besides the maturity level, the executive summary lists the key practices that were not satisfied, those that need improvement, and those that were missing. The process maturity profile indicates the degree of satisfaction of each key practice. Specific actions to improve existing key practices or to address missing key practices to move to the next higher level are described in the improvement action plan. See [10] for an example of an assessment report. See [12] 
for a proposed framework to face the action planning required to move on after conducting the assessments.

\section{ASSESSMENT RESULTS}

This section reports, for each version, the degree of key practice satisfaction from the assessments conducted for that version.

\section{Using Version 1}

The first version was released in March 1993. It was used to assess 26 projects at 7 companies in the time period March 1993 - September 1995, and Tables 4 and 5 show the results in terms of degree of satisfaction for each key practice and the overall results in terms of maturity levels.

Table 4. Key Practices and Degrees of Satisfaction - DPMM Version 1

\begin{tabular}{|c|c|c|c|c|}
\hline Level & Key Practices & Not & Partial & Fully \\
\hline 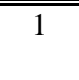 & $\begin{array}{l}\text { 1. Consistent creation of basic software development documents } \\
\text { 2. Documentation generally recognized as important }\end{array}$ & $\begin{array}{l}4 \% \\
12 \%\end{array}$ & $\begin{array}{c}77 \% \\
8 \%\end{array}$ & $\begin{array}{l}19 \% \\
81 \%\end{array}$ \\
\hline 2 & $\begin{array}{l}\text { 3. Written statement or policy about importance of documentation } \\
\text { 4. Adequate time and resources for documentation } \\
\text { 5. Adherence to documentation standards } \\
\text { 6. Use of check-off list of required documentation } \\
\text { 7. Use of simple documentation tools }\end{array}$ & $\begin{array}{l}38 \% \\
27 \% \\
19 \% \\
31 \% \\
4 \%\end{array}$ & $\begin{array}{l}12 \% \\
54 \% \\
69 \% \\
27 \% \\
8 \%\end{array}$ & $\begin{array}{l}50 \% \\
19 \% \\
12 \% \\
42 \% \\
88 \%\end{array}$ \\
\hline 3 & $\begin{array}{l}\text { 8. Accuracy and reliability of documentation } \\
\text { 9. Mechanisms to update documentation } \\
\text { 10. Mechanisms to monitor quality of documentation } \\
\text { 11. Methods to assess usefulness of documentation } \\
\text { 12. Use of common sets of documentation tools } \\
\text { 13. Use of advanced documentation tools } \\
\text { 14. Documentation-related technology and training }\end{array}$ & $\begin{array}{c}0 \% \\
65 \% \\
65 \% \\
77 \% \\
35 \% \\
65 \% \\
100 \%\end{array}$ & $\begin{array}{c}62 \% \\
31 \% \\
27 \% \\
15 \% \\
23 \% \\
23 \% \\
0 \%\end{array}$ & $\begin{array}{l}38 \% \\
4 \% \\
8 \% \\
8 \% \\
42 \% \\
15 \% \\
0 \%\end{array}$ \\
\hline 4 & $\begin{array}{l}\text { 15. Measures of documentation process quality } \\
\text { 16. Analysis of documentation usage and usefulness } \\
\text { 17. Process improvement feedback loop } \\
\text { 18. Integrate CASE and documentation tools }\end{array}$ & $\begin{array}{l}100 \% \\
96 \% \\
69 \% \\
73 \%\end{array}$ & $\begin{array}{l}0 \% \\
4 \% \\
23 \% \\
12 \%\end{array}$ & $\begin{array}{l}0 \% \\
0 \% \\
8 \% \\
15 \%\end{array}$ \\
\hline
\end{tabular}

Version 1 was used to assess 26 projects. Although only four out of the 26 projects classified defect data by development phase, there was one promising data point that supported the model. Three of the four projects were from the same organization. Two projects were assessed as a level 2 and one a level 1. The defect data indicated that for the one project at level 1, 41\% of the defects found during integration testing were design and requirements defects whereas for the two projects at level 2 only $25 \%$ of the defects found were design and requirements defects [2]. This strongly suggests that defects are indeed detected earlier in projects with a higher documentation maturity level. 
Table 5. Breakdown by Maturity Level - DPMM Version 1

\begin{tabular}{||c||c||}
\hline \hline Level & $\%$ \\
\hline \hline 1 & $62 \%$ \\
\hline 2 & $38 \%$ \\
\hline 3 & $0 \%$ \\
\hline 4 & $0 \%$ \\
\hline
\end{tabular}

The results from Table 4 show that most organizations are at level 1 . The higher the maturity level the lower the degree of satisfaction for the key practices in that level. It's important to contrast degree of satisfaction of practice 2 (Documentation generally recognized as important) with that of practice 4 (Adequate time and resources for documentation), or between practices 3 (Written statement or policy about importance of documentation) and 5 (Adherence to documentation standards). Both cases stress the need to move from good intentions to concrete actions.

\section{Using Version 2}

The second version was released in September 1995. It was used to assess 34 projects at 13 companies in 3 countries in the time period September 1995 - September 1996. Tables 6 and 7 show the results in terms of degree of satisfaction for each key practice and the overall results in terms of maturity levels.

Table 6. Key Practices and Degrees of Satisfaction - DPMM Version 2

\begin{tabular}{|c|c|c|c|c|c|c|}
\hline Level & Key Practices & $\mathrm{VL}$ & $\mathrm{L}$ & $\mathrm{M}$ & $\mathrm{H}$ & $\mathrm{VH}$ \\
\hline 1 & $\begin{array}{l}\text { 1. Consistent creation of basic software development documents } \\
\text { 2. Documentation generally recognized as important }\end{array}$ & $\begin{array}{c}0 \% \\
29 \%\end{array}$ & $\begin{array}{l}24 \% \\
6 \%\end{array}$ & $\begin{array}{c}53 \% \\
3 \%\end{array}$ & $\begin{array}{l}15 \% \\
12 \%\end{array}$ & $\begin{array}{l}9 \% \\
50 \%\end{array}$ \\
\hline 2 & $\begin{array}{l}\text { 3. Written statement or policy about importance of documentation } \\
\text { 4. Adequate time for documentation } \\
\text { 5. Existence of documentation policy or standards } \\
\text { 6. Adherence to documentation policy or standards } \\
\text { 7. Mechanism to check that required documentation is done } \\
\text { 8. Use of simple documentation tools }\end{array}$ & $\begin{array}{l}26 \% \\
18 \% \\
21 \% \\
65 \% \\
15 \% \\
0 \%\end{array}$ & $\begin{array}{l}12 \% \\
24 \% \\
21 \% \\
26 \% \\
26 \% \\
0 \%\end{array}$ & $\begin{array}{l}12 \% \\
26 \% \\
32 \% \\
3 \% \\
24 \% \\
9 \%\end{array}$ & $\begin{array}{c}9 \% \\
32 \% \\
18 \% \\
6 \% \\
15 \% \\
32 \%\end{array}$ & $\begin{array}{l}1 \% \\
0 \% \\
9 \% \\
0 \% \\
21 \% \\
59 \%\end{array}$ \\
\hline 3 & $\begin{array}{l}\text { 9. Accuracy and reliability of documentation } \\
\text { 10. Mechanisms to update documentation } \\
\text { 11. Methods to monitor quality of documentation } \\
\text { 12. Methods to assess usefulness of documentation } \\
\text { 13. Use of common sets of documentation tools } \\
\text { 14. Use of advanced documentation tools } \\
\text { 15. Documentation-related technology and training } \\
\text { 16. Documentation is traceable to previous documents }\end{array}$ & $\begin{array}{c}0 \% \\
65 \% \\
59 \% \\
85 \% \\
9 \% \\
53 \% \\
65 \% \\
53 \%\end{array}$ & $\begin{array}{l}18 \% \\
26 \% \\
32 \% \\
12 \% \\
12 \% \\
41 \% \\
26 \% \\
29 \%\end{array}$ & $\begin{array}{c}56 \% \\
9 \% \\
6 \% \\
0 \% \\
21 \% \\
3 \% \\
6 \% \\
15 \%\end{array}$ & $\begin{array}{c}26 \% \\
0 \% \\
3 \% \\
3 \% \\
24 \% \\
3 \% \\
3 \% \\
3 \%\end{array}$ & $\begin{array}{c}0 \% \\
0 \% \\
0 \% \\
0 \% \\
35 \% \\
0 \% \\
0 \% \\
0 \%\end{array}$ \\
\hline 4 & $\begin{array}{l}\text { 17. Measures of documentation process quality } \\
\text { 18. Analysis of documentation usage and usefulness } \\
\text { 19. Process improvement feedback loop }\end{array}$ & $\begin{array}{l}71 \% \\
85 \% \\
56 \%\end{array}$ & $\begin{array}{l}26 \% \\
12 \% \\
41 \%\end{array}$ & $\begin{array}{l}3 \% \\
3 \% \\
0 \%\end{array}$ & $\begin{array}{l}0 \% \\
0 \% \\
3 \%\end{array}$ & $\begin{array}{l}0 \% \\
0 \% \\
0 \%\end{array}$ \\
\hline
\end{tabular}


Table 7. Breakdown by Maturity Level - DPMM Version 2

\begin{tabular}{||c||c||}
\hline Level & $\%$ \\
\hline \hline 1 & $68 \%$ \\
\hline 2 & $29 \%$ \\
\hline 3 & $3 \%$ \\
\hline 4 & $0 \%$ \\
\hline
\end{tabular}

The results from using this version of the model are not substantially different from those obtained with the previous one. As the maturity levels increases the satisfaction of related key practices gets lower; the apparent contradiction between intentions and actions remains, evidenced by the decreasing degrees of satisfaction of practices 2 (Documentation generally recognized as important) and 4 (Adequate time for documentation), and 3 (Written statement or policy about importance of documentation), 5 (Existence of documentation policy or standards) and 6 (Adherence to documentation policy or standards).

\section{Using Version 3}

The third version was released in September 1996. It was used to assess 19 projects at 9 companies in 2 countries in the time period September 1996 - December 1998. See Tables 8 and 9.

Table 8. Key Practices and Degrees of Satisfaction - DPMM Version 3

\begin{tabular}{|c|c|c|c|c|c|c|}
\hline Level & Key Practices & VL & $\overline{\mathrm{L}}$ & $\mathrm{M}$ & $\mathrm{H}$ & $\mathrm{VH}$ \\
\hline 1 & No key practices - in this level there is only a set of basic practices & $0 \%$ & $6 \%$ & $28 \%$ & $50 \%$ & $17 \%$ \\
\hline 2 & $\begin{array}{l}\text { 2.1. Existence of documentation policy or standards } \\
\text { 2.2. Mechanism to check that required documentation is done } \\
\text { 2.3. Adherence to documentation policy or standards }\end{array}$ & $\begin{array}{c}6 \% \\
0 \% \\
33 \%\end{array}$ & $\begin{array}{l}11 \% \\
22 \% \\
39 \%\end{array}$ & $\begin{array}{l}33 \% \\
17 \% \\
0 \%\end{array}$ & $\begin{array}{l}17 \% \\
39 \% \\
17 \%\end{array}$ & $\begin{array}{l}33 \% \\
22 \% \\
11 \%\end{array}$ \\
\hline 3 & $\begin{array}{ll}\text { 3.1 } & \text { Existence of a defined process for creation of documents } \\
\text { 3.2 } & \text { Methods to assure quality of documentation } \\
\text { 3.3 } & \text { Assessment of usefulness of documentation }\end{array}$ & $\begin{array}{l}17 \% \\
6 \% \\
0 \%\end{array}$ & $\begin{array}{l}39 \% \\
56 \% \\
33 \%\end{array}$ & $\begin{array}{l}17 \% \\
22 \% \\
50 \%\end{array}$ & $\begin{array}{l}28 \% \\
17 \% \\
17 \%\end{array}$ & $\begin{array}{l}0 \% \\
0 \% \\
0 \%\end{array}$ \\
\hline 4 & $\begin{array}{l}\text { 4.1. Measures of documentation process quality and usefulness } \\
\text { 4.2. Analysis of documentation process quality and usefulness } \\
\text { 4.3. Process improvement feedback loop }\end{array}$ & $\begin{array}{l}39 \% \\
67 \% \\
50 \%\end{array}$ & $\begin{array}{l}44 \% \\
28 \% \\
22 \%\end{array}$ & $\begin{array}{l}11 \% \\
6 \% \\
22 \%\end{array}$ & $\begin{array}{l}6 \% \\
0 \% \\
6 \%\end{array}$ & $\begin{array}{l}0 \% \\
0 \% \\
0 \%\end{array}$ \\
\hline
\end{tabular}


Table 9. Breakdown by Maturity Level - DPMM Version 3

\begin{tabular}{||c||c||}
\hline Level & $\%$ \\
\hline \hline 1 & $72 \%$ \\
\hline 2 & $28 \%$ \\
\hline 3 & $0 \%$ \\
\hline 4 & $0 \%$ \\
\hline
\end{tabular}

Again, the results from this version are very similar to those of the previous versions. The degrees of satisfaction of practices 2.1 and 2.3 illustrate the big gap between the existence of the policy and the adherence to it.

\section{Using Version 4}

The fourth version was released in December 1998. It has been used to assess 12 projects in the time period December 1998 - present. Table 10 shows the results in terms of degree of satisfaction for each key practice. No maturity levels are computed for this version.

Table 10. Key Practices and Degrees of Satisfaction - DPMM Version 4

Key Practices

1. Creation of basic software documents

2. Management recognition of importance of documentation

3. Existence of documentation policy or standards

4. Monitor implementation of policy or standards

5. Existence of a defined process for creation of documents

6. Methods to assure quality of documentation

7. Assessments of usability of documentation

8. Definition of software documentation quality and usability measures

9. Collection and analysis of documentation quality measures

10.Collection and analysis of documentation usability measures

11. Process improvement feedback loop

\begin{tabular}{||c||c||c||c||c||}
\hline VL & $\mathrm{L}$ & $\mathrm{M}$ & $\mathrm{H}$ & $\mathrm{VH}$ \\
\hline $0 \%$ & $8 \%$ & $25 \%$ & $17 \%$ & $50 \%$ \\
$0 \%$ & $8 \%$ & $25 \%$ & $0 \%$ & $67 \%$ \\
$17 \%$ & $8 \%$ & $25 \%$ & $0 \%$ & $67 \%$ \\
$8 \%$ & $8 \%$ & $42 \%$ & $25 \%$ & $17 \%$ \\
$25 \%$ & $0 \%$ & $33 \%$ & $33 \%$ & $8 \%$ \\
$8 \%$ & $25 \%$ & $42 \%$ & $25 \%$ & $0 \%$ \\
$8 \%$ & $67 \%$ & $17 \%$ & $18 \%$ & $0 \%$ \\
$67 \%$ & $17 \%$ & $8 \%$ & $8 \%$ & $0 \%$ \\
$42 \%$ & $42 \%$ & $17 \%$ & $0 \%$ & $0 \%$ \\
$100 \%$ & $0 \%$ & $0 \%$ & $0 \%$ & $0 \%$ \\
$42 \%$ & $33 \%$ & $17 \%$ & $0 \%$ & $8 \%$ \\
& & & & \\
\hline
\end{tabular}

The results are not very different from the results provided by the assessments using the previous three versions. Once again there is a considerable gap between the intentions and the actions, as clearly illustrated by the degrees of satisfaction of practices 2 (Management recognition of importance of documentation), 3 (Existence of documentation policy or standards) and 4 (Monitor implementation of policy or standards). 


\section{SUMMARY AND CONCLUSIONS}

Software process maturity models are conceptual frameworks to improve software development and maintenance processes. They do not guarantee success in obtaining higher quality products or more efficient processes. To achieve these goals, there has to be a real commitment and actions to fulfill that commitment from the whole organization.

This paper has presented the results obtained from the assessments of 91 projects at 41 companies using a documentation process maturity model. Its purpose is to profile the key components of the system documentation process, and an assessment procedure whose goal is to determine how well an organization's documentation process matches that of the model. We developed a simple assessment questionnaire that takes a short time to complete and whose responses provide information for an assessment report that describes how the organization's process stands relative to the model and suggests changes to improve the process.

Our results show a clear picture of process immaturity and general software documentation process practice non-satisfaction. Not surprisingly, this is reflected in a steady decrease in key practice satisfaction expected in less mature organizations. The key practices are listed in a natural maturity order (e.g. practices of more mature organizations appear later in the list) that clearly show the trend. Assessed organizations mostly satisfy key practices linked to assuring the existence of policies or standards, but they fail for higher maturity key practices related to assuring the actual monitoring of compliance to these policies or standards. There is an acknowledgement of the problem but little action to back it up. The results also highlight the low satisfaction for key practices related to assuring the quality and usability of the actual documents produced. The main challenge is to make a serious effort to enhance the software documentation process, by adopting and carrying out explicit policies aimed at process improvement.

One crucial point that our experience has made very clear is the importance and fundamental role of the key practices. They drive the generation of the assessment questionnaire. When an organization's process is assessed relative to the model, the assessment is actually measuring the organization's degree of satisfaction of the key practices. That is, how well is the organization carrying out the key practices. In spite of this, the maturity level has been the most commonly used indicator of the organization's process maturity. The maturity level is such a broad indicator that it is of limited value as it provides incomplete information about which key practices are satisfied and which are not.

The results and analysis reported in this paper are part of a broad on-going research effort aimed at improving the whole software process. 


\section{ACKNOWLEDGMENTS}

We thank former students Patricio Antiman from Universidad Tecnica Federico Santa Maria and Sheldon Dealy from Oregon State University for their help in improving the questionnaires, conducting the assessments and tabulating the results over the first three versions. We are also grateful to all the software professionals whose invaluable input and support helped carry out this research effort over this many years.

\section{REFERENCES}

1. D. Card, F. McGarry and G. Page. Evaluating software engineering technologies. IEEE Transactions on Software Engineering, 13(7) (1987) 845-851.

2. C. Cook and M. Visconti. Documentation is important. CrossTalk, 7(11) (1994) 26-30.

3. C. Cook and M. Visconti. New and improved documentation process model, in Proceedings of the 14th Pacific Northwest Software Quality Conference, Portland, Oregon, October 1996 (PNSQC, Portland, 1996), pp. 364-380.

4. W. Humphrey. Managing the software process (Addison-Wesley, Reading, 1989).

5. B. Lientz and E. Swanson. Problems in applications software maintenance. Communications of the ACM , 24(11) (1981) 763-769.

6. M. Paulk, B. Curtis, M. Chrissis and C. Weber. The Capability Maturity Model guidelines for improving the software process (Addison-Wesley, Reading, 1995).

7. M. Paulk, B. Curtis, M. Chrissis and C. Weber. Capability Maturity Model, version 1.1. IEEE Software, 10(4) (1993) 18-27.

8. J. Pence and S. Hon III. Building software quality into telecommunications network systems. Quality Progress, (October 1993) 95-97.

9. H. Rombach and V. Basili. Quantitative assessment of maintenance: an industrial case study, in Proceedings of the IEEE Conference on Software Maintenance, Austin, Texas, September 1987 (IEEE, Washington, 1987), pp. 134-144.

10. M. Visconti and C. Cook. A software system documentation process maturity approach to software quality, in Proceedings of the 11th Pacific Northwest Software Quality Conference, Portland, Oregon, October 1993 (PNSQC, Portland, 1993), pp. 257-271.

11. M. Visconti and C. Cook. Evolution of a maturity model - critical evaluation and lessons learned. Software Quality Journal (2000) (to appear).

12. C. Cook and M. Visconti. What to do after the assessment report?, in Proceedings of the 17th Pacific Northwest Software Quality Conference, Portland, Oregon, October 1999 (PNSQC, Portland, 1999), pp. 214-228.

13. M. Visconti and C. Cook. A meta-model for software process maturity. Technical Report OSU/CS-00-60-07 (OSU/CS, Corvallis, Oregon, 2000). 